\title{
Actinomyces turicensis
}

National Cancer Institute

\section{Source}

National Cancer Institute. Actinomyces turicensis. NCI Thesaurus. Code C86114.

A species of anaerobic, Gram variable, rod shaped bacteria assigned to the phylum

Actinobacteria. This bacteria is catalase negative, does not reduce nitrate and does not

hydrolyze esculin, urea or gelatin. A. turicensis is most often related to genital, skin, and urinary tract infections. 